\title{
METHODS AND MEANS OF INCREASING THE RELIABILITY OF COMPUTERIZED MODULAR UNINTERRUPTIBLE POWER SUPPLY SYSTEM
}

\author{
Andriy Palamar \\ Ternopil Ivan Puluj National Technical University, Ternopil, Ukraine
}

\begin{abstract}
Summary. The problem of development and implementation of a simple and effective method of the rectifiers operation control for the modular uninterruptible DC power supply unit in order to increase its reliability is considered in this paper. The main idea of the method is to control the process of cyclic shifting of the switchedon power modules of the uninterruptible power supply by series switching into operation of each subsequent module from their unloaded reserve and switching out the previous one. The paper presents the control system structure where in addition to the central control module, it is proposed to add the control unit for power modules, which is responsible for implementing the process of their switching on and monitors their condition. In order to investigate the effectiveness of the proposed method, computer simulation model describing the power modules control logic is developed. The Simulink visual modeling environment and the mathematical tools of the Stateflow library component using state and transition diagrams are used in order to develop the simulation model. The developed simulation model is tested and the simulation results are given in the form of time diagrams of state change. The implementation of the developed method, due to the uniform reduction of the period during which the power modules of the uninterruptible power supply are on the switched-on loaded state, makes it possible to increase their operating time to failure, which in turn increases its reliability without deteriorating energy efficiency. The simulation results demonstrate the efficiency of the developed algorithm in various system operation modes. Based on the proposed method, hardware and software which is implemented as a part of intelligent computerized control system for uninterruptible DC power supply is created.
\end{abstract}

Key words: reliability, control system, uninterruptible power supply, simulation.

https://doi.org/10.33108/visnyk_tntu2020.03.133

Received 01.09.2020

Statement of the problem. At present, it is extremely important to provide reliable and high-quality electricity to critical infrastructure facilities - such as communications systems, telecommunications, data processing centers, medical centres, banking institutions, etc. The cost of problems caused by poor quality and/or reliability of electricity supply can be extremely high and can include downtime and equipment damage, data loss and power supply interruption in medical centres, which can result even in death. In order to avoid these problems, industrial uninterruptible power supplies (UPS) [1] are used, which provide uninterrupted power supply to consumer equipment for a long time in case of failure in general electrical power network. The application of UPS for power supply of critical application systems requires increased energy efficiency and reliability of their operation under all operating modes.

However, while designing UPS, there is a contradiction between the reliability of UPS functioning, which requires hot redundancy, additional energy consumption and energy efficiency of the power supply system. The known approaches concerning UPS reliability increase require certain compromise with the requirements to its energy efficiency. The improvement of both parameters is of great importance for many objects.

One of the most important components of modern UPS is control and monitoring systems responsible for measuring electrical parameters, alarm signals polling, control of the device operation modes, archiving and transmitting data to personal computer for storage and further processing, etc. Due to the intensive development of microprocessor technologies, 
computerized UPS control systems are becoming widely used making it possible to implement more efficient control algorithms. Although a lot of various industrial UPS models with modern computerized means of monitoring and controlling are used at present, the problems of creating new more effective methods and means of controlling uninterruptible power supply systems, optimizing their software and algorithmic solutions still remain underinvestigated.

Therefore, the development of software and hardware methods and tools for intelligent control and monitoring of uninterruptible power supplies is an important scientific and technical problem, the solution of which will increase their reliability and energy efficiency.

Analysis of available investigations results. The investigation results described in papers [2-6] showed that modular UPSs of both alternating and direct current have higher reliability indices than monolithic UPSs. In turn, the DC UPS system provides higher reliability indices, particularly the coefficient of readiness compared with that of AC UPS [7], which is due to the presence of greater number of components and subsystems in the latter ones.

It is shown in paper [8] that high fault tolerance of UPS is achieved due to the presence of modules redundancy $(\mathrm{N}+1),(\mathrm{N}+2), \ldots,(\mathrm{N}+\mathrm{M})$. If any of the modules fails, the load is redistributed between the other modules. "Hot"” redundancy provides zero downtime, as in order to replace the failed module, you do not need to turn off the device completely, because the remaining modules ensure the proper system functioning. However, the impact on energy efficiency is not analyzed in the paper.

The algorithm for automated design of DC and AC UPS based on the method of morphological synthesis is developed in paper [9]. The use of such algorithm makes it possible to increase the value of the important UPS reliability index - the average failure time. But the problem of changing and peak loads influence on UPS reliability are not highlighted.

The authors of paper [10] propose the model in the form of the states and transitions graph, which allows to take properly into account the reliable behavior of software and hardware system in case of faults and failures of both hardware and software.

The reliable model for automation of the fault-tolerant system designing process for UPS of round-the-clock long-term operation is developed in paper [11]. Unreliability of control, diagnostics and switching elements is taken into account. The dependence of the duration of trouble-free operation on the number of modules is investigated.

Paper [12] presents the investigation where reliability of distributed UPS control systems of two types is analyzed. Here the authors compare the reliability indices of UPS with a single-processor control board and UPS based on multiprocessor control boards using Markov models. As a result of the comparison it is determined that the multiprocessor control system provides better reliability indices of UPS operation.

The review and analysis of the known research results showed that existing methods and software - algorithm tools used to increase UPS reliability, particularly for increasing the redundancy of power modules, result in the system energy efficiency reduce. However, the ways for the improvement of energy efficiency indices are not considered in these papers.

Thus, we can conclude that till present, the efforts to develop effective and simple methods for increasing the reliability and ensuring high energy efficiency of uninterruptible power supplies operation having sufficient efficiency are being made.

Objective of the paper is to increase the reliability of the components of the uninterruptible power supply functioning without reduction of its energy efficiency by developing a new method of power modules control and improving its computerized control system.

Statement of the problem. In order to improve energy efficiency indices together with increasing the reliability of modular uninterruptible power supply systems, the author proposed and described in [13] the method of correction of the rectifiers total output power. However, as a result of the carried out investigations it is determined that the use of this method causes 
uneven operating time of modules in the loaded state. Therefore, in order to achieve the goal of this investigation, it is necessary to develop the control method enabling to obtain the uniform power modules operating time, reducing it to minimum. One of the most important tasks is to develop and investigate the simulation model of the control algorithm, which implements this method for testing its effectiveness.

Description of the method. The essence of this method is to control the process of cyclic shifting of the switched-on power modules of the uninterruptible power supply by series switching into operation of each subsequent module from their unloaded reserve and switching out the previous one. This makes it possible to increase their downtime, which in turn increases the uninterruptible power supply system reliability.

In detail the operation algorithm can be described in the following way. When starting the function that implements the method of correction of the rectifiers total output power, we calculate the predicted value of the number of UPS power modules, which must be left powered in order that their load factor is in the optimal values range at which their maximum operation energy efficiency is achieved. The load factor of UPS rectifiers is calculated by the formula [13]:

$$
K_{\text {load }}=\frac{\left(I_{\text {load }}+\sum_{i=1}^{m} I_{B A T i}\right) \cdot U_{\text {out }}}{N \cdot P_{\text {nom }}}
$$

where $I_{\text {load }}$ is current in the load circuit; $I_{B A T i}$ is current in circuit $i$ of the batteries groups (AB); $m$ - is the number of AB groups; $U_{\text {out }}$ is DC UPS output voltage; $N$ is the number of rectifiers in operating condition; $P_{n o m}$ is rated power of one rectifier.

After that the central control module sends the command via CAN bus to the rectifiers control unit for activating or deactivating the required number of power modules. If one or more modules are disconnected as a result of this switching, then the processes of their shifting are started for maintaining the uniform duration of their operation. The implementation of this process is schematically shown in Fig. 1 on the example of the system containing six power modules.

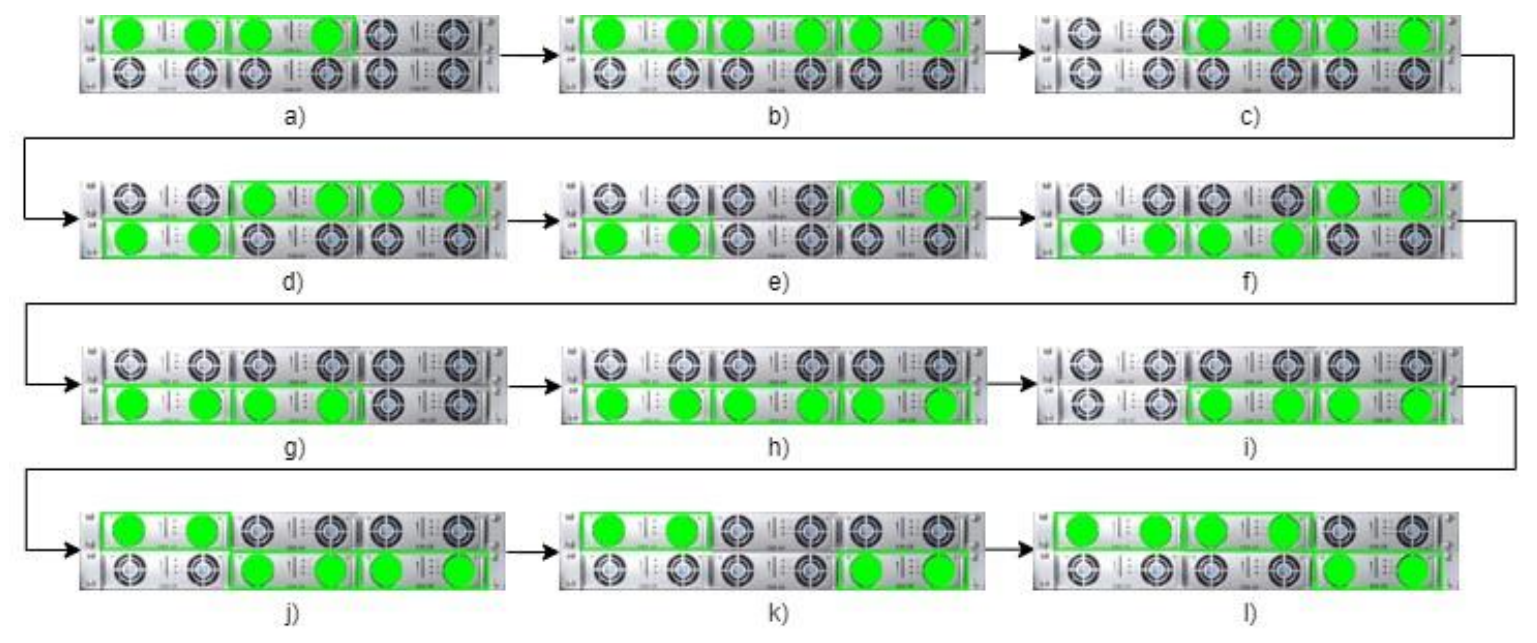

Figure 1. The process of shifting the switched-on loaded rectifiers of the modular uninterruptible power supply

Let us assume that in order to achieve the optimal load factor of the system, it is enough to leave two power modules in operation. At the first stage, two extreme modules located in the upper row on the left remain powered, and the rest are switched off (Fig. 1 a). After some time, 
the shifting cycle is started by connecting one additional module, as shown in Fig. 1 b. After a short period of time, from 20 to 30 seconds, making sure that the new power module has started successfully, the microcontroller switches off the first rectifier (Fig. $1 \mathrm{c}$ ). After this stage, the process of shifting the power modules transfers into standby mode and can range from a few hours to several days. After completion of this step, the process is repeated with the next power module, etc.

In order to implement this method the appropriate hardware for the improvement of UPS control system is developed. In addition to the central control module (CCM), which is responsible for monitoring and controlling the entire system, the rectifier control unit is developed as well. The block scheme of UPS control system, considered in this paper, is shown in Fig. 2.

The structure and principle of operation of the central control module are described in detail in the author's papers $[14,15]$. It controls all UPS operation modes, implements the process of monitoring the parameters of its subsystems and periodically saves the received data in non-volatile memory and transfers them to the operator's computer. The rectifier control unit (RCD) is responsible for implementing the process of switching on and off the power modules and monitors their condition. The CAN interface is used to organize the exchange of information between CCM and RCD. Due to its high reliability level, it is best one for data and command transmission in the distributed UPS control system.

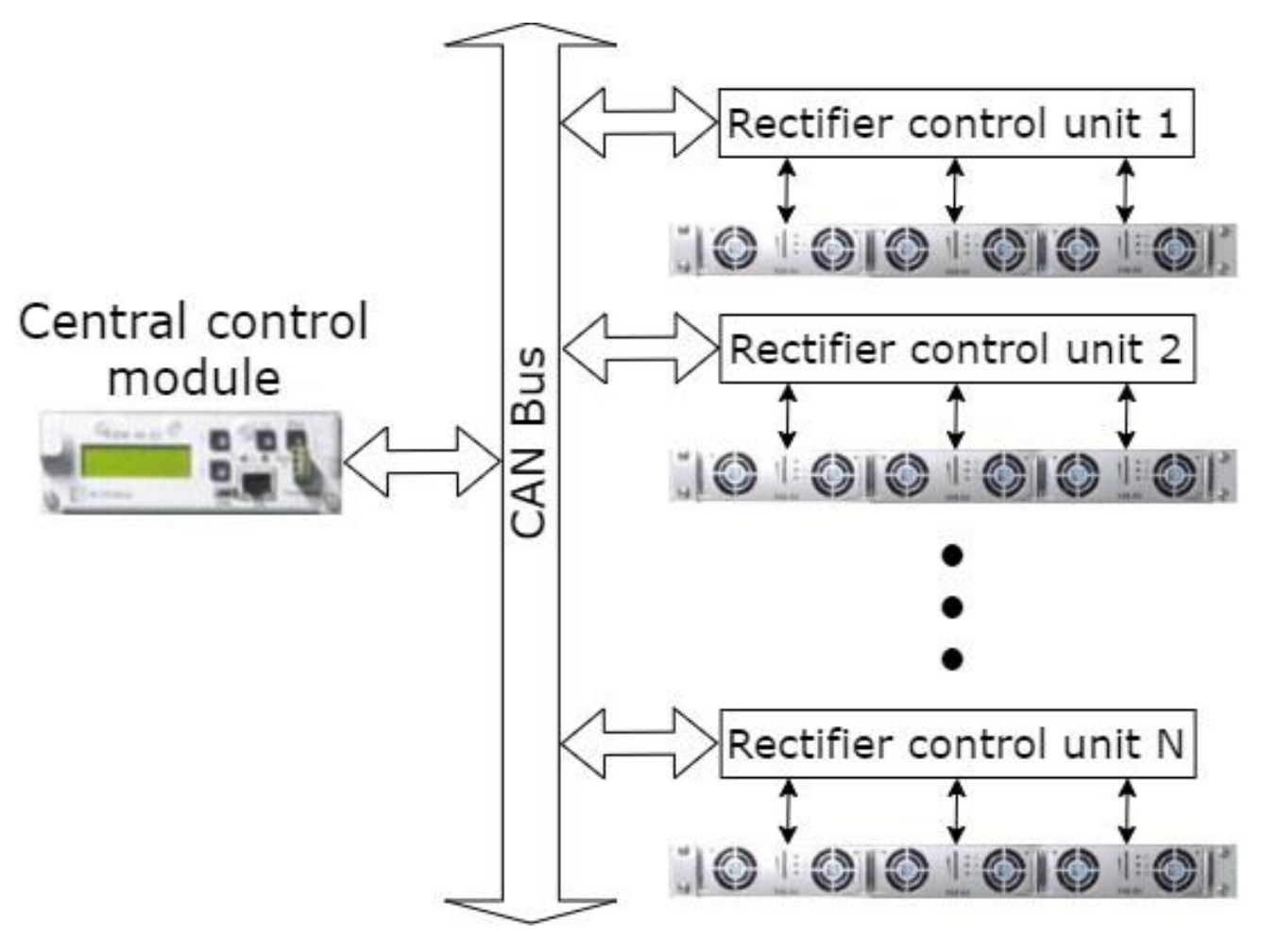

Figure 2. Block scheme of the control system of uninterruptible power supply modules

Simulation model. For the investigation of the proposed method effectiveness, a simulation model of the control system for three power modules of the uninterruptible power supply is developed. Here the corresponding algorithm of its operation is implemented. The Simulink visual modeling environment and the mathematical apparatus of the Stateflow component library using state and transition diagrams are used to develop the model. 
The improved simulation model of UPS power module control algorithm, which is shown in Fig. 3, is constructed on the basis of the model described in the previous author's investigation [13]. It is a set of the following elements:

1. A set of input signals: $U_{\text {out }}$ is UPS output voltage; $I_{\text {load }}$ is load current; $I_{\text {batl }}, I_{\text {bat } 2}$ are currents flowing in batteries circuits.

2. Input parameters of control syste: $K_{\max }, K_{\min }$ are upper and lower threshold levels of the rectifiers load coefficient which values in this model are 0.8 та 0.5 respectively; $P_{\text {nom }}$ is rated power of one power module which in the given UPS is $2 \mathrm{~kW}$. In general this system is provided with 3 rectifiers.

3. Blocks Control Logic 1 and Control Logic 2, containing the implementation of control logic in the form of states and transition diagrams.

4. Blocks Result1 and Result2 are designet for simulation results display.

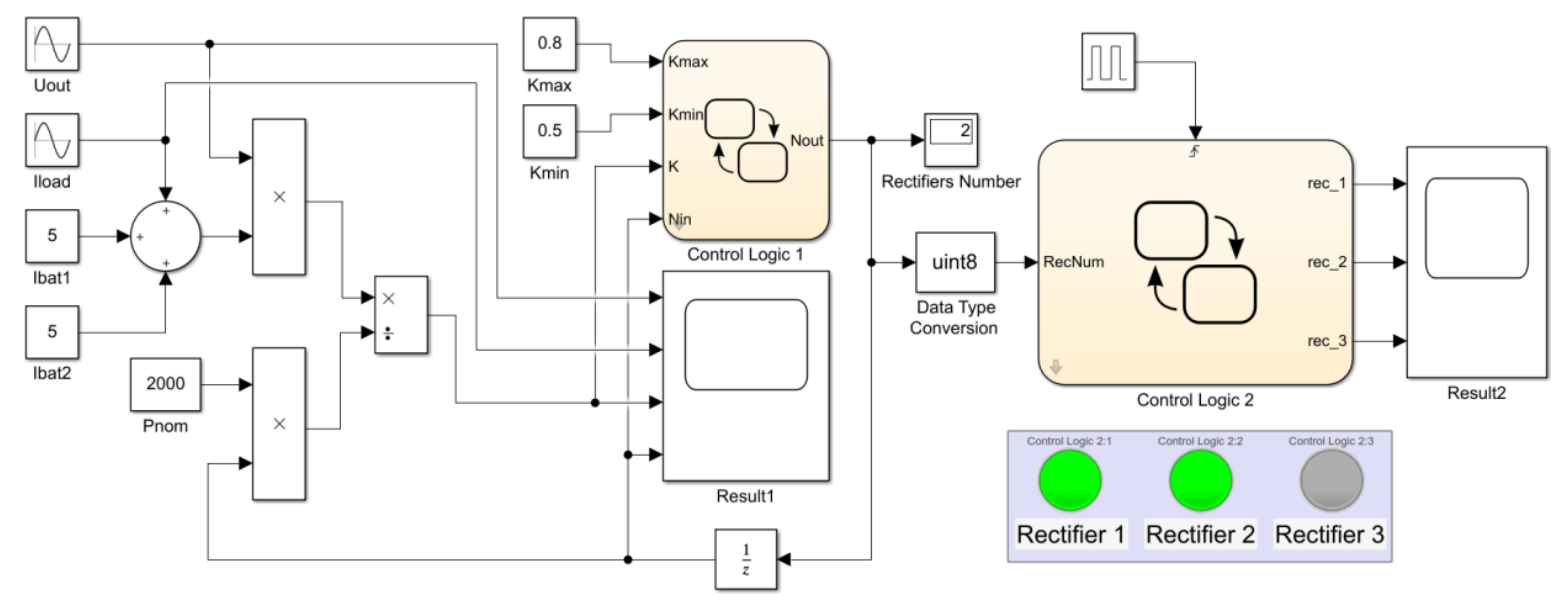

Figure 3. Improved simulation model of UPS power modules control algorithm

Block Control Logic 1 unit, described in detail in [13], implements the calculation of the required number of rectifiers which shoul be connected in order that their load factor is within the optimal values range. Block Control Logic 2, constructed using states and transitions diagrams (Fig. 4) of Stateflow library, implements the control algorithm of the displacement process for the switched on power modules of the uninterruptible power supply system.

At the initial stage of the algorithm, all power modules are in the powered state. The RecNum input signal specifies the number of modules to be switched on simultaneously during their rotation. This number depends on the value of the power modules load coefficient which is defined as the ratio of power consumption to the UPS rated power. Depending on this value the transition to the corresponding block (Rec1of3, Rec2of3 or Rec3of3) is carried out. The first two blocks contain six alternating each other states. The transition time between these states specified in the settings of Control Logic 2 component, can be short (RecTime) and long (RotTime). The duration of the short time interval is from 20 to 40 seconds. During this time, the next UPS power module is connected in the process of their rotation. The duration of the long time interval can be from several hours to several days depending on the settings. It corresponds to the operation period of each subsequent combination of the switched on UPS power modules. 


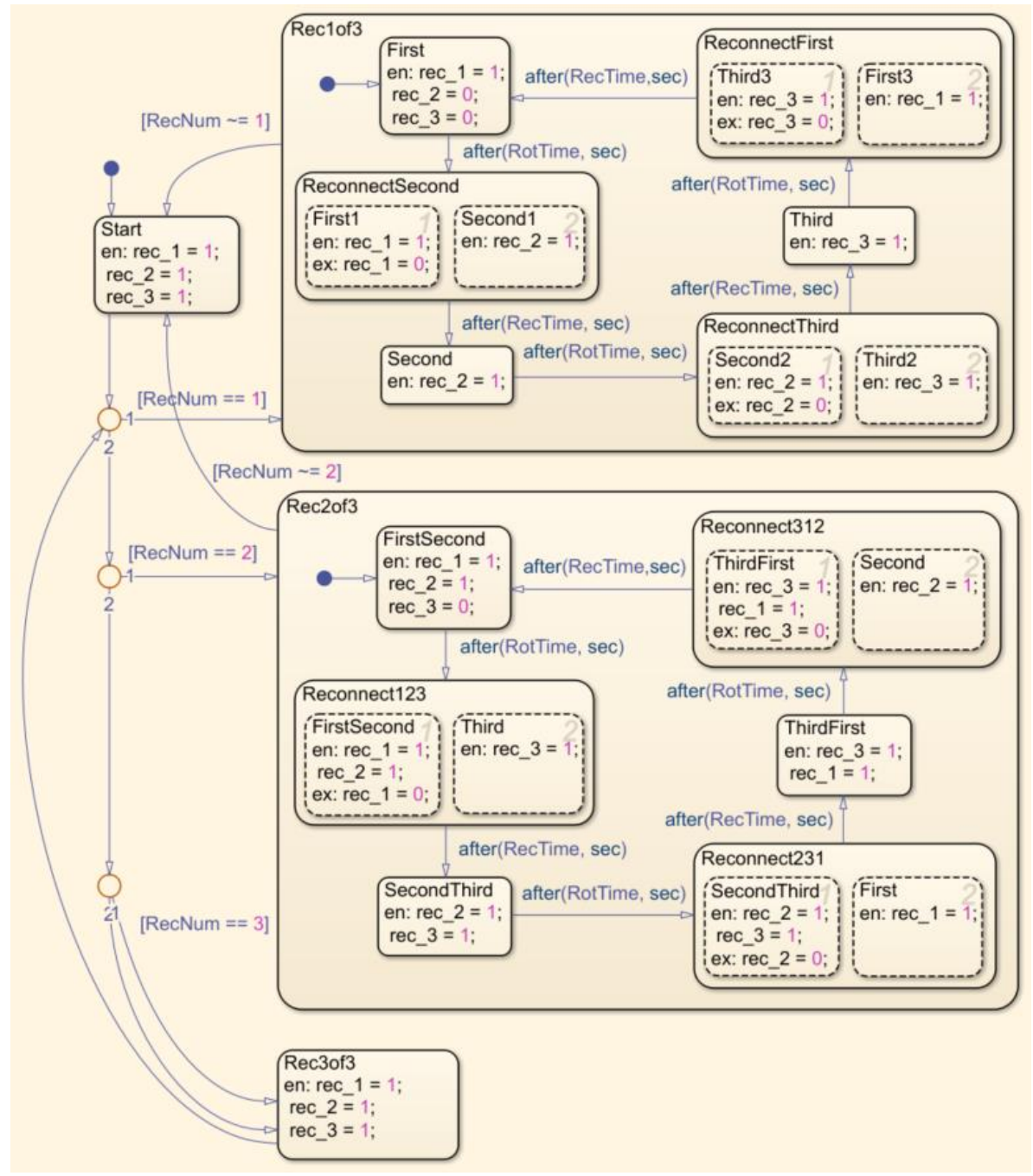

Figure 4. States and transitions block diagram of the control algorithm for the shifting process of the switched-on power modules for the computerized uninterruptible power supply system

Simulation results. For UPS control system containing three rectifiers, simulation is carried out. Its results are shown in the form of oscillograms of Result 2 block. Fig. 5 represents timing diagrams of the change of power modules state for the case of combination of one of the three switched on UPS power modules (Fig. 5 a) and combination of two of the three switched on UPS power modules (Fig. 5 b). High signal level corresponds to the switched on state of the relative module, and low one corresponds to the switched off state.

It is evident from the simulation results that the switching the power modules is carried out in such a way that at least one of them always remains on. During the implementation of the next cycle of rectifiers shifting, at first the next module is switched on, and after some time, which corresponds to the duration of the transient process, the previous one is turned off.

From the above given oscillograms we can conclude that the proposed method provides uniform power modules operating time of. And its application together with the method of correction of the total rectifiers output power makes it possible to reduce the total duration of their operation by $33 \%$ in case of simultaneous operation of two modules and by $67 \%$ in case of simultaneous operation of one module, which in turn increases time to failure of the uninterruptible power supply system. 

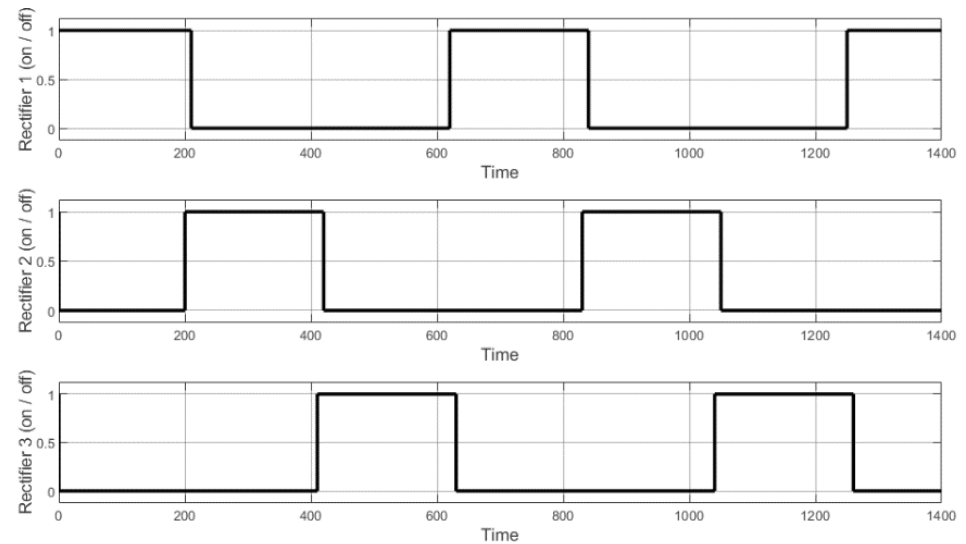

a)
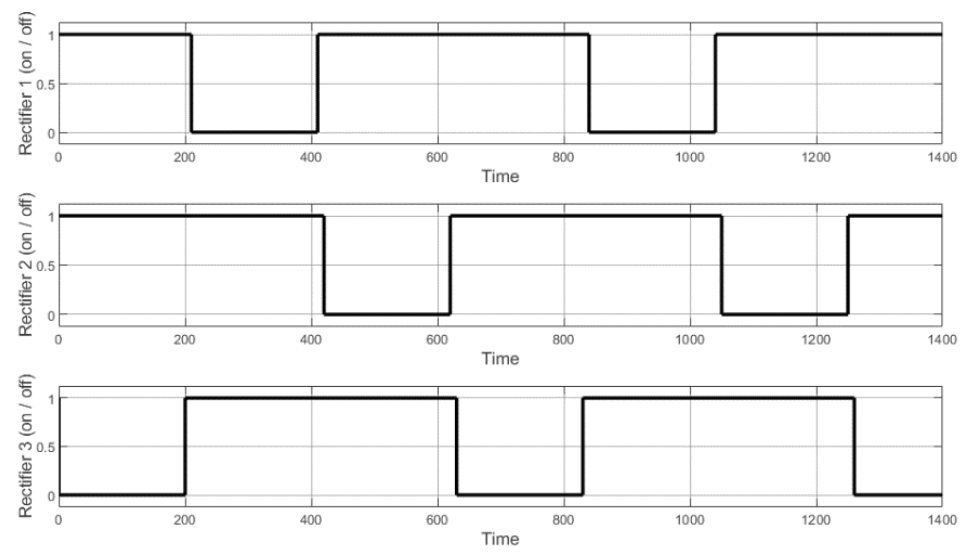

b)

Figure 5. The results of simulation the modular UPS control system in the mode of cyclic shifting of the switched-on rectifiers: a) time diagram of the change of the on and off states of the combinations of one of the three UPS power modules; b) timing diagram of the on and off states of two of the three UPS power modules

Conclusions. The proposed method of cyclic shifting of UPS loaded power modules, due to the uniform reduction of the time during which they are in switched on state, makes it possible to increase their operating time to failure, which is one of the most important indicators of reliability.

The developed software and hardware complex due to the expansion of its algorithmic support, based on the proposed method, makes it possible to increase the reliability of the components of modular computerized uninterruptible power supply system without its energy efficiency deterioration.

\section{References}

1. Andriychuk V., Filyuk Y. Autonomous power supply system for outdoor illumination of residential areas in the territory of Ukraine. Scientific Journal of TNTU. 2018. Vol. 89. No. 1. P. 113-121. https://doi.org/10.33108/visnyk_tntu2018.01.113

2. Shrestha B. R., Hansen T. M., Tonkoski R. Reliability analysis of 380V DC distribution in data centers. IEEE Power \& Energy Society Innovative Smart Grid Technologies Conference (ISGT). 2016. P. 1-5. https://doi.org/10.1109/ISGT.2016.7781271

3. Talapko D. Telecom datacenter power infrastructure availability comparison of DC and AC UPS. International Telecommunications Energy Conference (INTELEC). 2012. P. 1-5. https://doi.org/10.1109/INTLEC.2012.6374509 
4. Saro L., Zanettin C., Božič V. Reliability analysis and calculations for different power system architectures based on modular UPS. IEEE International Telecommunications Energy Conference (INTELEC). 2018. P. 1-8. https://doi.org/10.1109/INTLEC.2018.8612341

5. Saro L., Zanettin C., Božič V. Reliability analysis and calculation for the most common modular UPS system architectures. IEEE International Telecommunications Energy Conference (INTELEC). 2017. P. 91-98. https://doi.org/10.1109/INTLEC.2017.8211685

6. Xiaofei Z., Zhen W., Zhou S. How to ensure the modular UPS with high reliability. IEEE International Telecommunications Energy Conference (INTELEC). 2015. No. 1. P. 3-6. https://doi.org/10.1109/INTLEC.2015.7572450

7. Shrestha B. R., Tamrakar U., Hansen T. M., Bhattarai B. P., James S., Tonkoski R. Efficiency and reliability analyses of AC and 380 v DC distribution in data centers. Amer. Power Convers., Schnieder Electr., White Paper. 2018. Vol. 127. P. 63305-63315. https://doi.org/10.1109/ACCESS.2018.2877354

8. Artyushenko V. M., Abbasova T. S. Osobennosti rezervirovaniya istochnikov besperebojnogo pitaniya kompyuternogo i telekommunikacionnogo oborudovaniya. Elektrotexnicheskie i informacionnye kompleksy`i sistemy. 2007. Vol. 3. No. 3. P. 20-23. [In Russian].

9. Rogulina L. G. Avtomatizaciya proektirovaniya sistem elektropitaniya dlya predpriyatij svyazi. Vestnik Tambovskogo gosudarstvennogo texnicheskogo universiteta. 2011. Vol. 4. No. 17. P. 927-931. [In Russian].

10. Volochii B. Y., Ozirkovskyi L. D., Chopei R. S., Mashchak A. V., Shkiliuk O. P. Otsinka nadiinosti prohramno-aparatnykh system za dopomohoiu modeli yikh povedinky. Visnyk Natsionalnoho universytetu "Lvivska politekhnika". 2014. No. 796. P. 222-231. [In Ukrainian].

11. Volochii B. Y., Kuznietsov D. S. Model dlia nadiinisnoho proektuvannia dzherel bezperebiinoho elektrozhyvlennia radioelektronnykh informatsiinykh system tsilodobovoi dovhotryvaloi ekspluatatsiiRadioelektronika i informatika. 2012. No. 2. P. 36-42. [In Ukrainian].

12. Addabbo T., Fort A., Mugnaini M., Vignoli V. Distributed UPS control systems reliability analysis. Measurement. 2017. Vol. 110. P. 275-283. https://doi.org/10.1016/j.measurement.2017.06.021

13. Palamar A. Control system simulation by modular uninterruptible power supply unit with adaptive regulation function. Scientific Journal of TNTU. 2020. Vol. 98. No. 2. P. 129-136. https://doi.org/10.33108/visnyk_tntu2020.02.129

14. Palamar A., Karpinskyy M., Vodovozov V. Design and implementation of a digital control and monitoring system for an AC/DC UPS. 7th International Conference-Workshop "Compatibility and Power Electronics" CPE 2011. Tallinn, Estonia. 2011. P. 173-177. https://doi.org/10.1109/CPE.2011.5942227

15. Palamar A., Karpinskyy M. Control of an Uninterruptible Power Supply in a DC Microgrid System. 10th International Symposium Symposium "Topical Problems in the Field of Electrical and Power Engineering" and "Doctoral School of Energy and Geotechnology II". Pärnu, Estonia. 2011. P. 80-84.

\section{Список використаної літератури}

1. Andriychuk V., Filyuk Y. Autonomous power supply system for outdoor illumination of residential areas in the territory of Ukraine. Scientific Journal of TNTU. 2018. Vol. 89. No. 1. P. 113-121. https://doi.org/10.33108/visnyk_tntu2018.01.113

2. Shrestha B. R., Hansen T. M., Tonkoski R. Reliability analysis of 380V DC distribution in data centers. IEEE Power \& Energy Society Innovative Smart Grid Technologies Conference (ISGT). 2016. P. 1-5. https://doi.org/10.1109/ISGT.2016.7781271

3. Talapko D. Telecom datacenter power infrastructure availability comparison of DC and AC UPS. International Telecommunications Energy Conference (INTELEC). 2012. P. 1-5. https://doi.org/10.1109/INTLEC.2012.6374509

4. Saro L., Zanettin C., Božič V. Reliability analysis and calculations for different power system architectures based on modular UPS. IEEE International Telecommunications Energy Conference (INTELEC). 2018. P. 1-8. https://doi.org/10.1109/INTLEC.2018.8612341

5. Saro L., Zanettin C., Božič V. Reliability analysis and calculation for the most common modular UPS system architectures. IEEE International Telecommunications Energy Conference (INTELEC). 2017. P. 91-98. https://doi.org/10.1109/INTLEC.2017.8211685

6. Xiaofei Z., Zhen W., Zhou S. How to ensure the modular UPS with high reliability. IEEE International Telecommunications Energy Conference (INTELEC). 2015. No. 1. P. 3-6. https://doi.org/10.1109/INTLEC.2015.7572450

7. Shrestha B. R., Tamrakar U., Hansen T. M., Bhattarai B. P., James S., Tonkoski R. Efficiency and reliability analyses of AC and 380 v DC distribution in data centers. Amer. Power Convers., Schnieder Electr., White Paper. 2018. Vol. 127. P. 63305-63315. https://doi.org/10.1109/ACCESS.2018.2877354

8. Артюшенко В. М., Аббасова Т. С. Особенности резервирования источников бесперебойного питания компьютерного и телекоммуникационного оборудования. Электротехнические и информационные комплексы и системы. 2007. Вип. 3. № 3. С. 20-23. 
9. Рогулина Л. Г. Автоматизация проектирования систем электропитания для предприятий связи. Вестник Тамбовского государственного технического университета. 2011. Вип. 4. № 17. С. 927-931.

10. Волочій Б. Ю., Озірковський Л. Д., Чопей Р. С., Мащак А. В., Шкілюк О. П. Оцінка надійності програмно-апаратних систем за допомогою моделі їх поведінки. Вісник Національного університету «Львівська політехніка». 2014. № 796. С. 222-231.

11. Волочій Б. Ю., Кузнєцов Д. С. Модель для надійнісного проектування джерел безперебійного електроживлення радіоелектронних інформаційних систем цілодобової довготривалої експлуатації. Радиоэлектроника и информатика. 2012. № 2. С. 36-42.

12. Addabbo T., Fort A., Mugnaini M., Vignoli V. Distributed UPS control systems reliability analysis. Measurement. 2017. Vol. 110. P. 275-283. https://doi.org/10.1016/j.measurement.2017.06.021

13. Palamar A. Control system simulation by modular uninterruptible power supply unit with adaptive regulation function. Scientific Journal of TNTU. 2020. Vol. 98. No. 2. P. 129-136. https://doi.org/10.33108/visnyk_tntu2020.02.129

14. Palamar A., Karpinskyy M., Vodovozov V. Design and implementation of a digital control and monitoring system for an AC/DC UPS. 7th International Conference-Workshop «Compatibility and Power Electronics» CPE 2011. Tallinn, Estonia. 2011. P. 173-177. https://doi.org/10.1109/CPE.2011.5942227

15. Palamar A., Karpinskyy M. Control of an Uninterruptible Power Supply in a DC Microgrid System. 10th International Symposium Symposium «Topical Problems in the Field of Electrical and Power Engineering» and «Doctoral School of Energy and Geotechnology II». Pärnu, Estonia. 2011. P. 80-84.

\title{
УДК 004.02:681.518:621.311
}

\section{МЕТОДИ І ЗАСОБИ ПІДВИЩЕННЯ НАДІЙНОСТІ КОМП'ЮТЕРИЗОВАНОЇ МОДУЛЬНОЇ СИСТЕМИ БЕЗПЕРЕБІЙНОГО ЖИВЛЕННЯ}

\author{
Андрій Паламар \\ Тернопільський національний технічний університет імені Івана Пулюя, \\ Тернопіль, Украӥна
}

\begin{abstract}
Резюме. Розглянуто питання розроблення та реалізації простого й ефективного методу керування роботою випрямлячів модульного джерела безперебійного живлення постійного струму з метою підвищення його надійності. Основна ідея методу полягає у керуванні проиесом ичиклічного змішення ввімкнених силових модулів джерела безперебійного живлення шляхом послідовного включення в роботу кожного наступного модуля з числа їх ненавантаженого резерву та відключення попереднього. В роботі наведено структуру системи керування, до складуякої, крім изентрального керуючого модуля, запропоновано ввести блок керування силовими модулями, який відповідає за реалізацію процесу їх комутації та здійснює моніторинг їх стану. Для дослідження ефективності запропонованого методу розроблено комп'ютерну імітаційну модель, яка описує логіку керування силовими модулями. Для розроблення імітаційної моделі використано середовище візуального моделювання Simulink та математичний апарат бібліотеки компонентів Stateflow із застосуванням діаграм станів та переходів. Виконано тестування розробленої імітаційної моделі та наведено результати моделювання у вигляді часових діаграм зміни станів. Застосування розробленого методу, завдяки рівномірному зменшенню часу, протягом якого силові модулі джерела безперебійного живлення знаходяться у ввімкненому навантаженому стані, дає змогу збільшити час їх напращювання на відмову, щзо, в свою чергу, підвищує його надійність без погіршення показників енергоефективності. Результати моделювання демонструють ефективність розробленого алгоритму в різних режимах роботи системи. На основі запропонованого методу створено апаратно-програмне забезпечення, реалізоване в якості складової інтелектуальної комп'ютеризованої системи керування джерелом безперебійного живлення постійного струму.
\end{abstract}

Ключові слова: надійність, система керування, джерело безперебійного жсилення, імітаційне моделювання. 